\title{
開水路等流の粘性底層およびバッファー層 における水理特性 \\ CHARACTERISTICS OF VISCOUS SUBLAYER AND BUFFER LAYER OF A 2-D OPEN CHANNEL FLOW
}

\author{
鬼束幸樹 1 ・襧津家久 2 \\ Kouki ONITSUKA and Iehisa NEZU \\ 1 正会員 博（工） 京都大学大学院助手 環境地球工学尃攻（干606-8501 京都市左京区吉田本町） \\ 2 正会員 工博 京都大学大学院教授 環境地球工学専攻
}

\begin{abstract}
The inner layer, consisting of viscous sublayer, buffer layer and the log layer, of a 2-D open channel flow was measured accurately with a laser Doppler anemometer. It was found that friction velocities evaluated from both linear formula in viscous sublayer and the log-law were in a good agreement with each other. The mean stream velocity profile can be expressed well by using of van Driest damping function and that van Driest damping factor is the universal constant. It was suggested that vertical turbulence intensity in the inner region can be expressed using of van Driest damping function.
\end{abstract}

Key Words : uniform flow, viscous sublayer, turbulence, van Driest damping factor

\section{1.はじめに}

開水路流は粘性底層, buffer 層および $\log$ 則領域に よって構成される内層と外層とに分けられる.

外層での特性は水深によって支配されているため， それを用いた無次元座標(外層表示)によって水理量 が普遍表示できる．ただし，外層での主流速分布を 理論的に導きだすことは現在に至るまで成功してい ないため, 何らかの経験則が必要となる.Nezu \& Rodi ${ }^{1}$ は $\log$ 則に wake 関数を付加した log-wake 則を 開水路流に初めて導入した. log-wake 則は物理的意 味が薄いという欠点を有しているが, 開水路流外層 における主流速分布を良好に表現できるため，現在 広く用いられている。また, log-wake 則に含まれる wake strength parameter $\Pi$ は, 摩擦速度を代表速度, 水深を代表長さとしたときの Reynolds 数が 500 以下 でゼロとなり, Reynolds 数が 500 から 2500 の領域で Пが急増し, 2500 以上では一定值 0.2 をとることが Nezu \& Rodi'1)によって明らかにされた.さらに，外 層の乱れ強度分布に関しては, Reynolds 数および Froude 数に影響を受けず, 指数関数的な分布を示す ことが襧津 ${ }^{2)}$ によって明らかにされた。

一方, 内層での特性は, 摩擦速度および動粘性係 数によって支配されているため，それらを用いた無 次元座標(内層表示)によって水理量が普遍表示でき
る. 粘性底層での流速分布は直線分布となることが 運動方程式から理論的に導かれ, $\log$ 則領域での流速 分布は $\log$ 則によって表現できることが半理論的に 示される.また, 粘性底層と $\log$ 則領域との中間に位 置する buffer 層における流速分布は, van Driest のダ ンピング関数を導入することで表現できる.ただし， $\log$ 則に含まれるKarman 定数 $\kappa$, 積分定数 $A$ および van Driest のダンピング係数 $B$ は理論的には求める ことができず, 実験より求めなければならない.Nezu \& Rodi ${ }^{1}$ は Reynolds 数および Froude 数を系統的に変 化させた 2 次元開水路等流を詳細に計測し, Karman 定数 $\kappa$, 積分定数 $A$ および van Driest のダンピング係 数 $B$ が Reynolds 数および Froude 数の影響を受けず, それそれれ $\kappa=0.41, A=5.3, B=26$ の普遍定数を示す ことを明らかにした。

さらに, Nezu \& Rodi ${ }^{1}$ は, 流下方向の乱れ強度分 布が粘性底層においては直線分布となり，その勾配 $C$ が 0.3 となることおよび buffer 層においては van Driest のダンピング関数を導入することで表現でき， van Driest のダンピング係数 $B_{u^{\prime}}$ が 10 となることも実 験的に示した。これらの值は現在基準值として広く 用いられている。しかし，粘性底層および buffer 層 における鉛直方向乱れ強度分布に関しては，流下方 向乱れ強度と異方性が強まることが境界層流の特性 を基に類推されているが, 測定結果がないために推 
測の域をでない。

このように開水路等流の特性は, 内層と外層とで はかなり異なることが明らかになっているが，スペ クトル特性に関しては, buffer 層, $\log$ 則領域および 外層の領域において，慣性小領域で Kolmogoroff の5/3 乗則が成立し, 粘性領域において Heisenberg)の7 乗則や椿・小松 ${ }^{4)}$ の- $13 / 3$ 乗則などが成立すること が明らかにされている。しかし，粘性底層における スペクトル分布にも同様な法則が成立するかどうか は，現在のところ不明である。

以上のことから，開水路流の基本となる 2 次元開 水路等流の特性は，外層においてはかなり明らかに されているものの，粘性底層付近における特性はそ れほど明らかにされていないのが現状といえる。本 研究では, 4 ビームファイバー型レーザー流速計を用 いて粘性底層, buffer 層を含む内層と外層とを詳細に 計測し，底面近傍における特性を初めて明らかにし たものである。

\section{2. 理論的考察}

本章では，2 次元開水路等流の平均流速分布，乱 れ強度分布およびReynolds応力分布などの理論式ま たは経験式を示し，加えて，まだ明らかにされてい ない分布について考察する。

水路床に沿って流下方向に $x$ 軸を, $x$ 軸に直角上向 きに $y$ 軸を定義し， $x$ 軸および $y$ 軸方向それぞれの 時間平均流速を $U$ および $V$ とし，乱れ強さを $u^{\prime}$ およ び $v^{\prime}$ とする．完全に発達した 2 次元開水路流のせん 断応力 $\tau$ の分布は, $x$ 軸方向の運動方程式を変形する ことで次式のように示される.

$$
\frac{\tau}{\rho U_{*}^{2}}=\frac{-\overline{u v}}{U_{*}^{2}}+\frac{d U^{+}}{d y^{+}}=1-\frac{y^{+}}{R_{*}}
$$

ここに, $\rho$ は水の密度, $U *$ は摩擦速度, $-\overline{u v}$ は Reynolds応力, $U^{+}=U / U *$ は無次元時間平均流速, $y^{+}=y U_{*} / v$ は無次元座標, $v$ は動粘性係数, $R_{*}=h U_{*} / v$ はReynolds数, $h$ は水深である. 式(1)は せん断応力がReynolds応力と粘性応力によって構成 されていることを示す.さて, 式(1)におけるReynolds 応力をPlandt1の混合距離仮説を用いて消去すると，

$$
\frac{d U^{+}}{d y^{+}}=\frac{2(1-\xi)}{1+\sqrt{1+4 \ell^{+2}(1-\xi)}}
$$

となる.ここに， $\xi=y / h$ であり, $\ell^{+}$は次式で示さ れる。

$$
\begin{gathered}
\ell^{+}=\kappa y^{+} \Gamma \\
\Gamma=1-\exp \left(-\frac{y^{+}}{B}\right)
\end{gathered}
$$

Гは van Driest のダンピング関数で， $B$ はダンピン グ係数である。等流の場合は，B=26となることが Nezu \& Rodi ${ }^{1}$ によって示されている.
表-1 実験条件

\begin{tabular}{|c|c|c|c|c|c|c|}
\hline case & $\begin{array}{c}h \\
\mathrm{~cm}\end{array}$ & $F r$ & $\begin{array}{c}R e \\
\times 10^{3}\end{array}$ & $\begin{array}{c}\mathrm{v} \\
\mathrm{cm} / \mathrm{s}\end{array}$ & $\begin{array}{c}U_{*_{1}} \\
\mathrm{~cm} / \mathrm{s}\end{array}$ & $\begin{array}{c}U_{* 2} \\
\mathrm{~cm} / \mathrm{s}\end{array}$ \\
\hline $\mathrm{R} 573$ & 7.2 & 0.15 & 10.1 & 12.5 & 0.709 & 0.705 \\
\hline $\mathrm{R} 381$ & 7.2 & 0.10 & 6.7 & 8.3 & 0.472 & 0.497 \\
\hline $\mathrm{R} 246$ & 7.2 & 0.05 & 3.4 & 4.2 & 0.304 & 0.311 \\
\hline
\end{tabular}

粘性底層 $\left(0<y^{+} \leq 5\right)$ では, $d U^{+} / d y^{+}>-\overline{u v} / U_{*}{ }^{2}$ となるので, 式(2)は次式に変形できる.

$$
U^{+}=y^{+}
$$

一方, バッファー層を越えると $-\overline{u v} / U_{*}{ }^{2}>>$ $d U^{+} / d y^{+}$となるので，式(2)は次式となる.

$$
U^{+}=\frac{1}{\kappa} \ln y^{+}+A
$$

等流においては, Reynolds数およびFroude数に関わら ず, $\kappa=0.41 A=5.3$ の普遍定数を示すことがNezu \& Rodi ${ }^{1}$ によって明らかにされた。 $R_{*}<500$ のような低 Reynolds数の開水路等流では, 主流速分布が全水深に わたりほぼ式(6)で表現できるが，高Reynolds数にお いては, 水面付近で $\log$ 則からずれが生じるため, 次 式のlog-wake則が用いられる.

$$
U^{+}=\frac{1}{\kappa} \ln y^{+}+A+\frac{2 \Pi}{\kappa} \sin ^{2}\left(\frac{\pi}{2} \xi\right)
$$

乱れ強度分布に関しては，以下のような半経験式

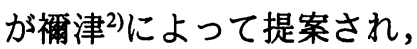

$$
\begin{aligned}
& \frac{u^{\prime}}{U_{*}}=D_{u} \exp \left(-\lambda_{u} \xi\right) \\
& \frac{v^{\prime}}{U_{*}}=D_{v} \exp \left(-\lambda_{\nu} \xi\right)
\end{aligned}
$$

Nezu \& Rodi ${ }^{1}$ のレーザ流速計の計測よって, 基準值 $D_{u}=2.26, D_{v}=1.23, \lambda_{u}=0.88, \lambda_{v}=0.67$ が実験的に 求められた。また，壁面付近の内部変数によって支 配されている領域においては, 乱れ強度 $u^{\prime} / U$ *は次式 に従うことが明らかにされている。

$$
\frac{u^{\prime}}{U_{*}}=D_{u} \exp \left(-\lambda_{u} \frac{y^{+}}{R_{*}}\right) \Gamma+C y^{+}(1-\Gamma)
$$

等流では，ダンピング係数 $B_{u^{\prime}}$ は 10 をとり，C は 0.3 をとる.さらに，粘性底層では，右辺第 1 項よりも， 右辺第 2 項の方が支配項となり，

$$
\frac{u^{\prime}}{U_{*}}=C y^{+}
$$

で示される。

一方, 乱れ強度 $v^{\prime}$ の底面付近における分布は，境 界層流においては乱れ強度 $u^{\prime}$ に対する異方性が強ま ることが実験およびDNSによって明らかにされてい るものの，開水路流においては未だ不明である。

\section{3．実験装置および実験方法}

実験に用いた水路は, 長さ $10 \mathrm{~m}$, 幅 $40 \mathrm{~cm}$, 高さ $50 \mathrm{~cm}$ 


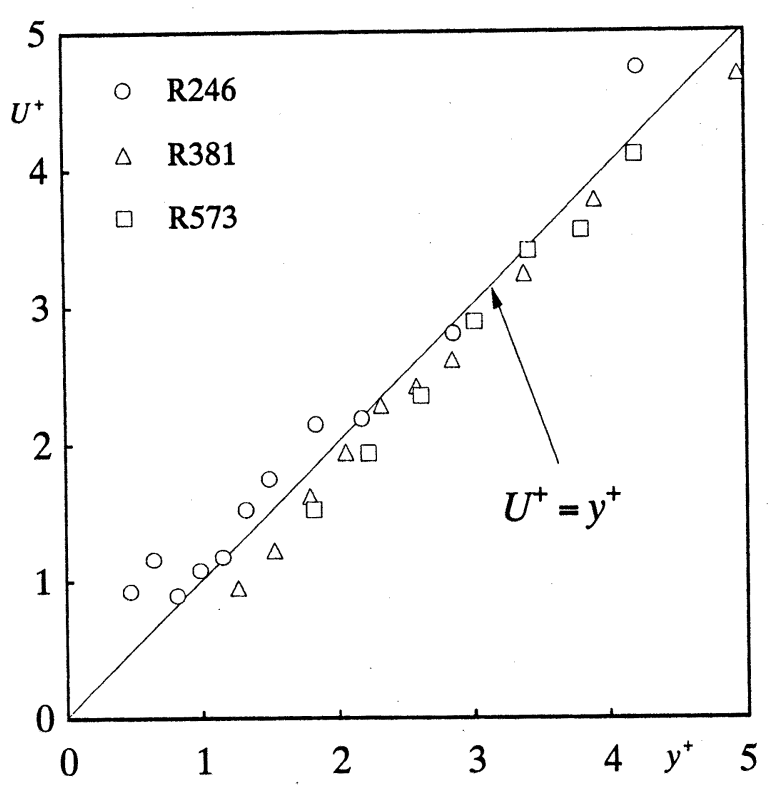

図-1＼cjkstart粘性底層における主流速分布

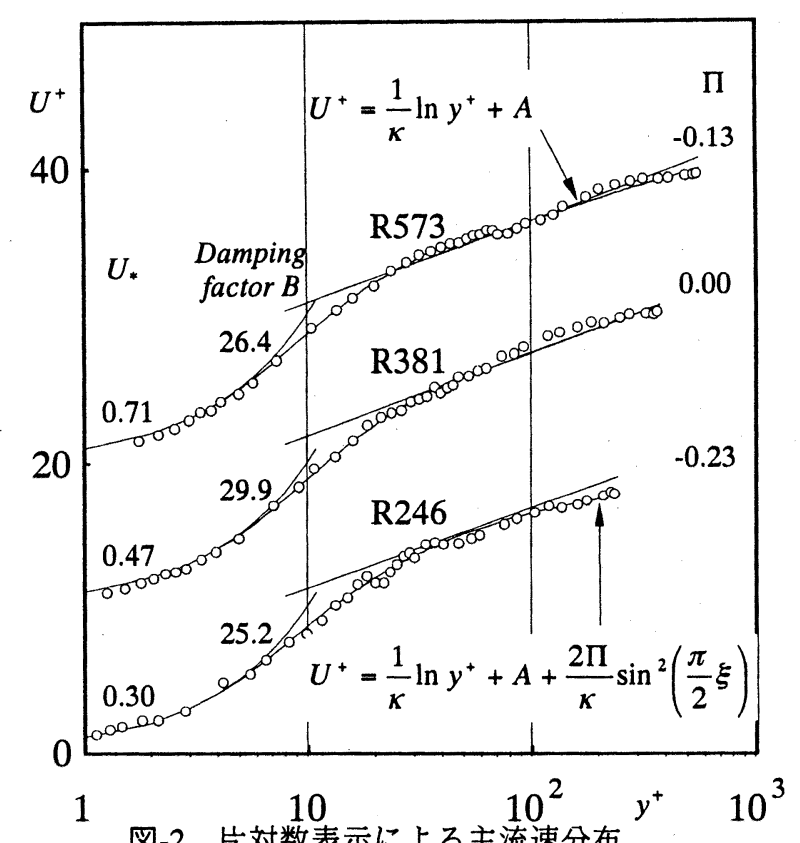

の可変勾配水路である.瞬間流速の測定には 4 ビー ム後方散乱型ファイバーレーザー流速計を用いた。

実験条件は, Reynolds数を変化させた 3 ケースであ る. 実験条件を表-1に示す.ここに， $F r=v / \sqrt{g h}$ は Froude数, $R e=v h / v$ はReynolds数, $\mathrm{v}$ は断面平均流 速, $g$ は重力加速度, $U_{*_{1}}, U_{*_{2}}$ はそれそれ粘性底層 および $\log$ 則より求めた摩擦速度（詳細については後 述する）であり，測定時間は60sである．これらの 3 ケースはReynolds数のみならず, Froude数も変化して いるが，底面付近の挙動に及ぼすFroudeの影響はほ

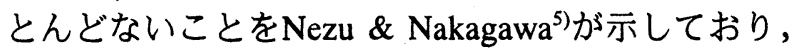
また，本実験条件のFroude数は限界流に比べ非常に 小さく，Froude数による影響を無視しうるものと考

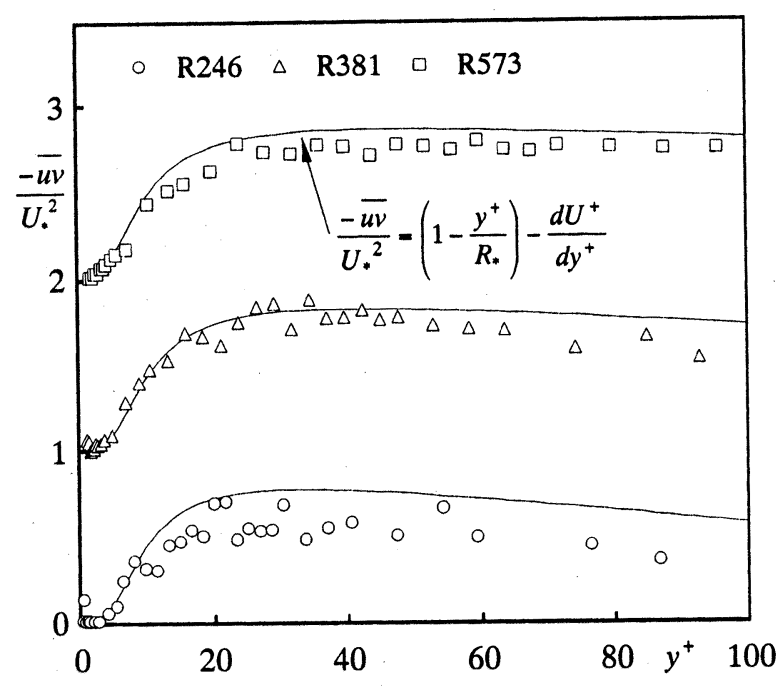

図-3 Reynolds応力分布

える。

\section{4. 実験結果および考察}

（1）主流速分布および摩擦速度の評価

図-1は粘性底層 $0<y^{+} \leq 5$ から求められた摩擦速度 により無次元化された主流速分布を示している。い ずれのケースもほぼ式(5)に適合していることが分か る.これは, 本実験の平均流速測定精度が高いこと を示すものである.また, Reynolds数による影響は認 められない。

図-2は粘性底層から求めた摩擦速度によって無次 元化された主流速分布の片対数表示である.同図よ り $5<y^{+} \leq 40$ のバッファー層では式(2)に，40< $y^{+}$では 式(6)に適合していることが分かる . また， $40<y^{+} \leq 0.2 R_{*}$ の主流速分布を式(6)に当てはめて摩 擦速度を求めたところ, 表-1に示したようにほぼ一致 した。これは，従来から用いられてきた $\log$ 則による 摩擦速度の評価が妥当であることを示す。

次に, $5<y^{+} \leq 400 ハ ゙ ッ フ ァ ー$ 層において式(2)を当 てはめて van Driestのダンピング係数 $B$ を求めた．ダ ンピング係数 $B$ は 3 ケースともNezu \& Rodi ${ }^{11}$ が提唱 した26の值を示し, Reynolds数への依存性は認められ なかった。図-2中に式(2)を曲線で示しているが，バ ッファー層の主流速分布が式(2)にようて良好に表現 できることが分かる。

図-3に内層表示によるReynolds応力分布をプロッ トで，式(1)を実線で示している，R246の実測值はゃ や理論式(1)より小さな值を示している。これは，流 速が遅いため, 测定時間内に測定体積を通過する散 乱粒子の数が少なかったことが一因として考えられ， 今後, 長時間測定をする必要があると考えている. しかし，R573やR381の実測值はおおむね式(1)に適合 している. 


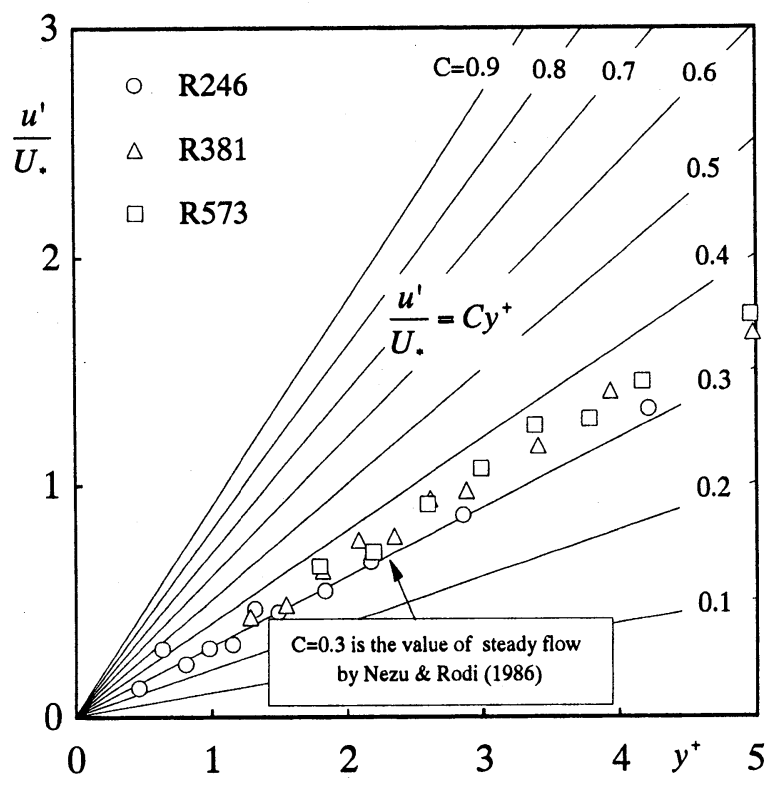

図-4 粘性底層における流下方向乱れ強度分布

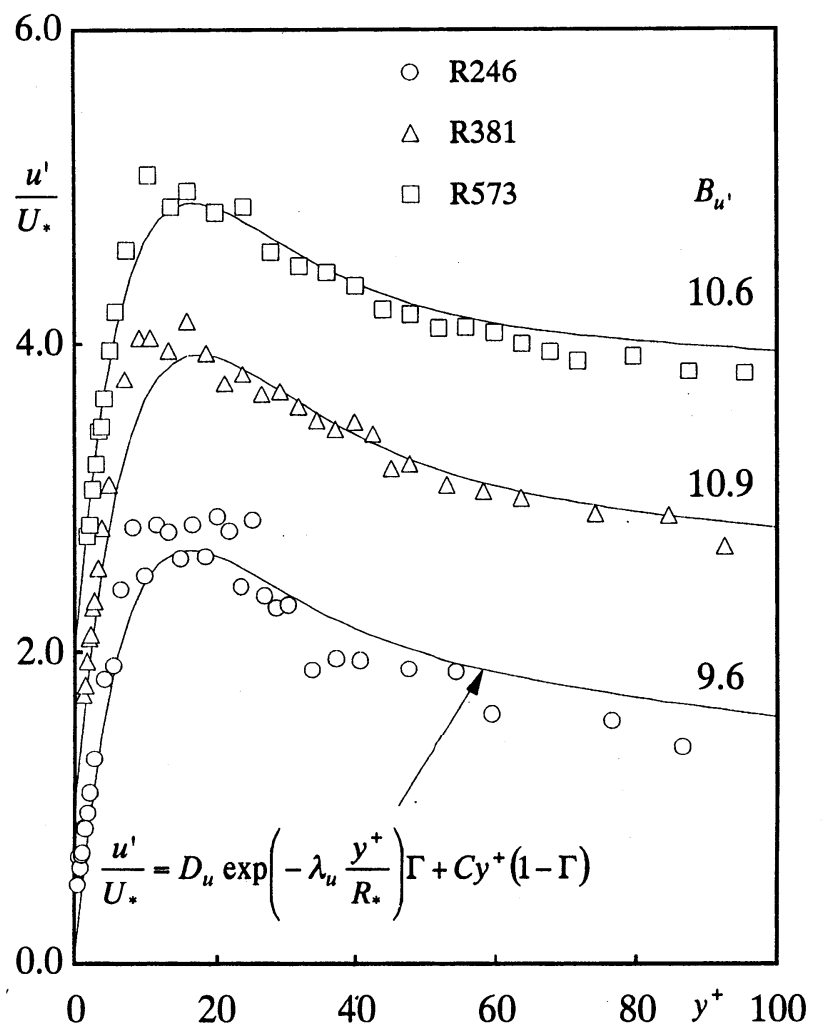

図-5 流下方向乱れ強度分布

（2）流下方向乱れ特性

図-4は粘性底層 $0<y^{+} \leq 5$ における流下方向乱れ強 度分布 $u^{\prime} / U_{*}$ を示している.多少のばらつきはあるが， ほぼ線形な分布となっている。そこで，実測值を式 (11)に当てはめて最小自乗法により $C$ を求めた。 R246, R381, R573のC はそれぞれ0.31, 0.34, 0.35であ つた.

図-5は内層表示された流下方向乱れ強度分布を示 している. $5<y^{+} \leq 40$ における実測値を式(10)に当て はめて, 最小自乗法によりダンピング係数 $B_{u^{\prime}}$ を求め

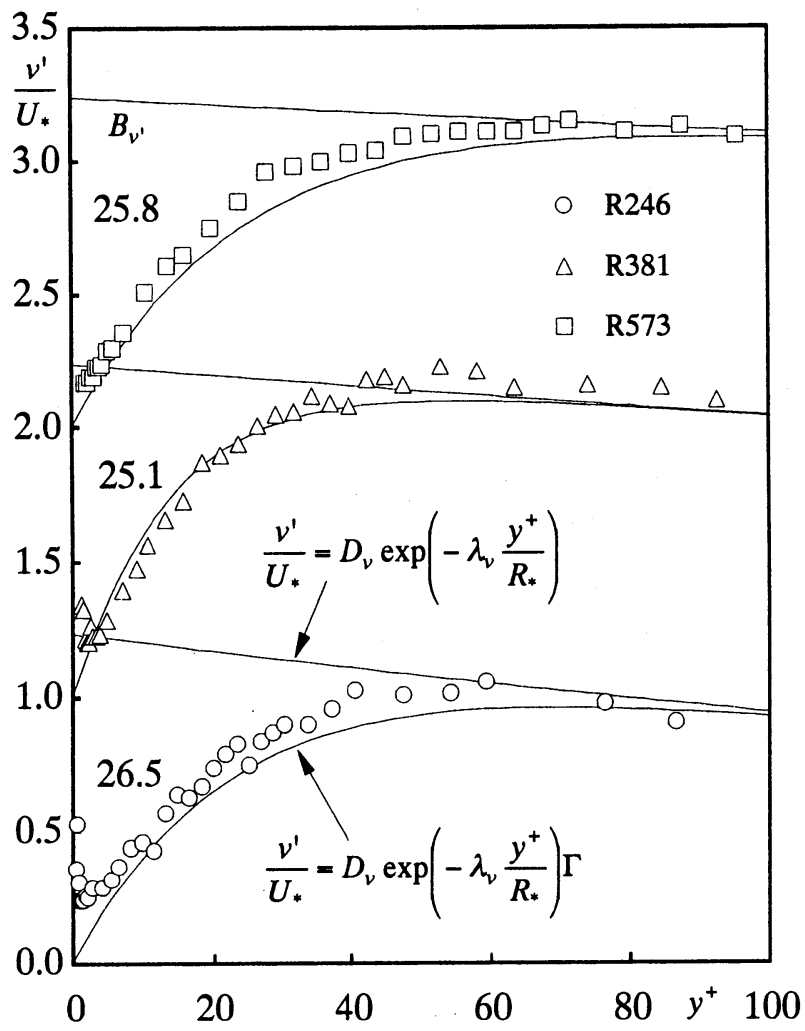

図-6 鉛直方向乱れ強度分布

た. 求めた $B_{u^{\prime}}$ による式(10)を図-5に示しているが， 良好に実測值を表現しているといえる。

\section{（3）鉛直方向乱れ特性}

粘性底層及びバッファー層における流下方向乱れ 強度はNezu \& Rodi ${ }^{1}$ によって測定され，式(10)および 式(11)によって表現できることが示されているが,鉛 直方向乱れ強度に関しては，その実験結果および経 験式が明らかにされていない，そこで，以下に鉛直 方向乱れ強度の実測値を示し，さらに，その分布を 表現できる経験式を提案する。

図-6は内層表示された鉛直方向乱れ強度の分布を 示している. 図中における右下がりの曲線は, 襧津 ${ }^{2}$

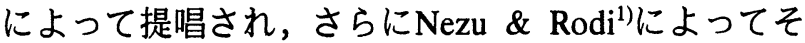
の係数值が高精度に求められた鉛直方向乱れ強度分 布式(9)である.バッファー層よりも離れた領域にお ける鉛直方向乱れ強度の実測值は，ほぼ式(9)に適合 しているが，壁面に近づくに従い式(9)より減少して いる.これは，壁面の存在により鉛直方向の乱れが 抑制されるためで, 従来境界層流の測定においては 認められていたものである．極めて底面付近では逆 に増加しているが，これは測定の限界を示したもの か流速の取り込み設定が悪いものか現段階では判断 しかねる. 今後の課題としたい. また，流下方向乱 れ強度が壁面付近 $\left(y^{+} \approx 17\right)$ でピーク值を示すのに 対し，鉛直方向乱れ強度はピーク值を示さず，底面 からなだらかに上昇していく．このように，壁面付 近における鉛直方向乱れ強度は式(9)よりダンピング するため，次式を提案する。 


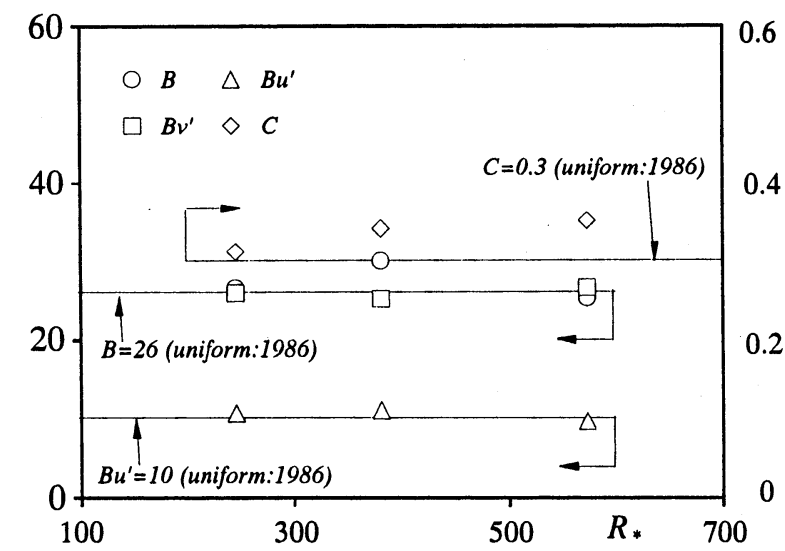

図-7 内層の水理特性量に及ぼすReynolds数 による影響

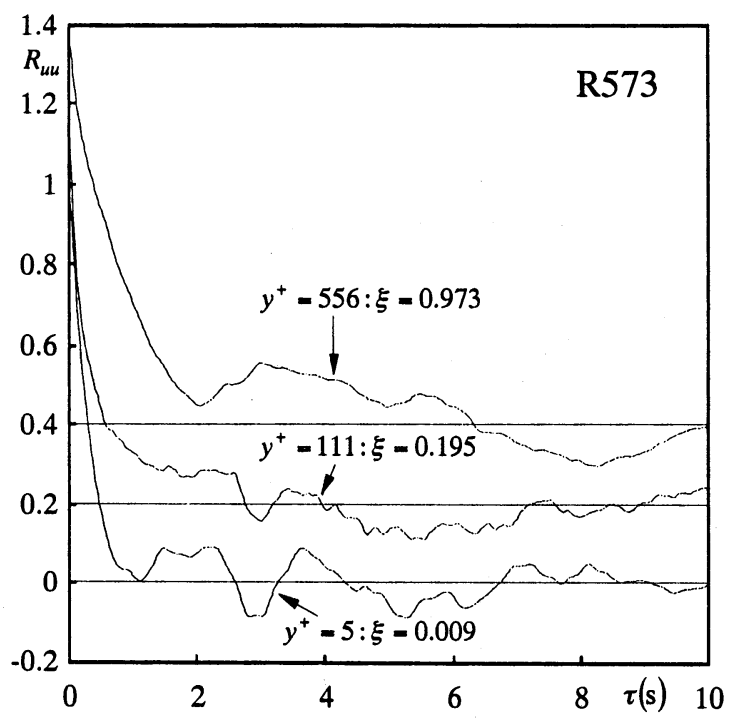

図-8 自己相関係数

$$
\frac{v^{\prime}}{U_{*}}=D_{\nu} \exp \left(-\lambda_{\nu} \frac{y^{+}}{R_{*}}\right) \Gamma
$$

ダンピング関数 $\Gamma$ は式(4)と同様な形式であり，ダン ピング係数を $B_{v^{\prime}}$ とする.

そこで,最小自乗法を用いて式(12)よりダンピング 係数 $B_{v^{\prime}}$ を求めた. 式(12)を図-6に示しているが，良 好に実測值を表現しているといえる。 また，ダンピ ング係数 $B_{v^{\prime}}$ は，R246，R381，R573においてそれぞれ 25.2, 29.9, 26.4であり，主流速分布におけるダンピン グ係数 $B$ とほぼ同一になる。

\section{（4）粘性底層およびバッファー層に及ぼす Reynolds} 数の影響

粘性底層およびバッファー層における特性を表す ものとして, 主流速分布におけるダンピング係数 $B$, 流下方向および鉛直方向乱れ強度のダンピング係数 $B_{u^{\prime}} ， B_{v^{\prime}}$ および粘性底層における流下方向乱れ強度 の傾き $C$ である. 図-7はReynolds数に対する $B, B_{u^{\prime}}$, $B_{v^{\prime}}$ および $C$ の挙動を示したものである.これらの諸 量のReynolds数への依存性は認められない。また，

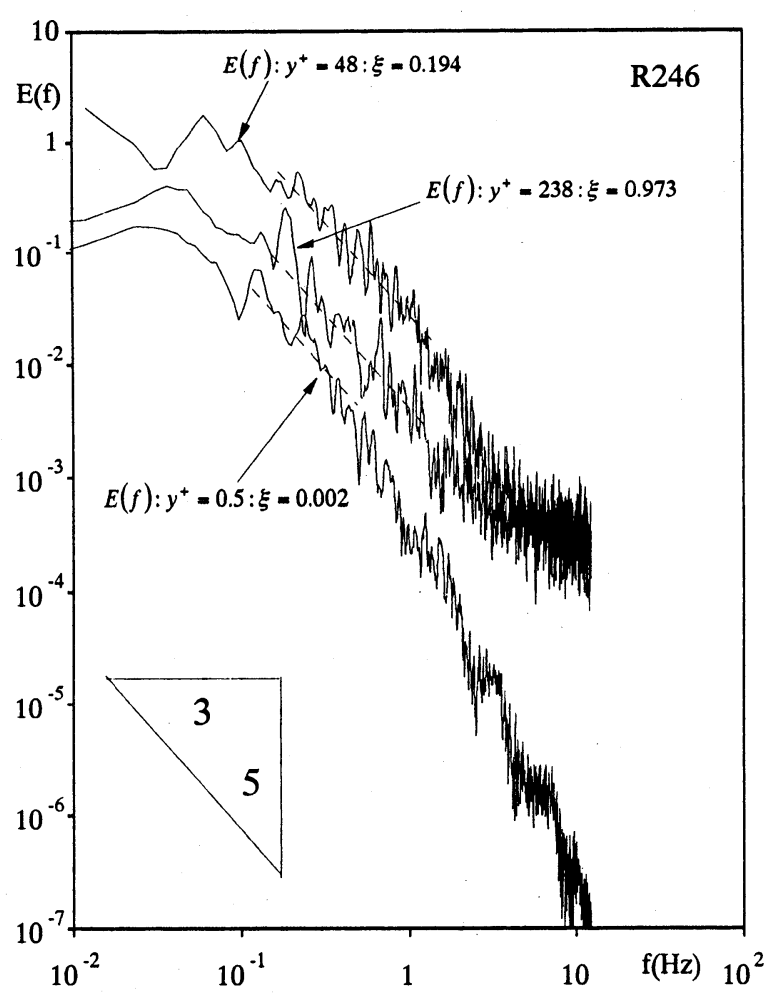

図-9 スペクトル分布

$B ， B_{u^{\prime}} ， B_{v^{\prime}}$ および $C$ はNezu \& Rodi ${ }^{1}$ によって提唱 されている值とほぼ一致している. 本研究で提案さ れた式(12)に用いられる $B_{v^{\prime}}$ に関しては，今後 Reynoldsを広範囲に変化させてその挙動を調べる必 要がある。

\section{(5) 自己相関係数}

自己相関係数 $R$ は平均量からの変動成分を $q$, ラ グタイムを $\tau$ とすると，次式で示される.

$$
R(\tau)=\overline{q(t) \times q(t+\tau)} / \overline{q(t)^{2}}
$$

図-8はR573における流下方向乱れ変動成分の自己相 関係数 $R_{u u}$ を示している. 図中には, 粘性底層領域, $\log$ 則領域およびwake領域における例を示している が, 壁面から離れるに従い, 自己相関係数がゼロと 交わる時間が徐々に増加しており，また，その周期 も長くなっていることから, 乱流スケールが増加し ていることが伺える.

\section{（6）スペクトル分布特性}

一般に, buffer 層, $\log$ 則領域および wake 領域にお いて, 慣性小領域で Kolmogoroff の-5/3 乗則が成立す ることは明らかにされているが，開水路流の粘性底 層におけるスペクトル分布特性については, 現在の ところ不明である.図-9は R246における粘性底層, $\log$ 則領域および wake 領域における $u^{\prime}$ のスペクトル 分布を実線で示したものである。それぞれの点にお いてスペクトルの傾きが-5/3 を示す慣性小領域が存 在するようである。ただし，図中に点線で示すよう に,粘性底層における慣性小領域の範囲は $\log$ 則領域 


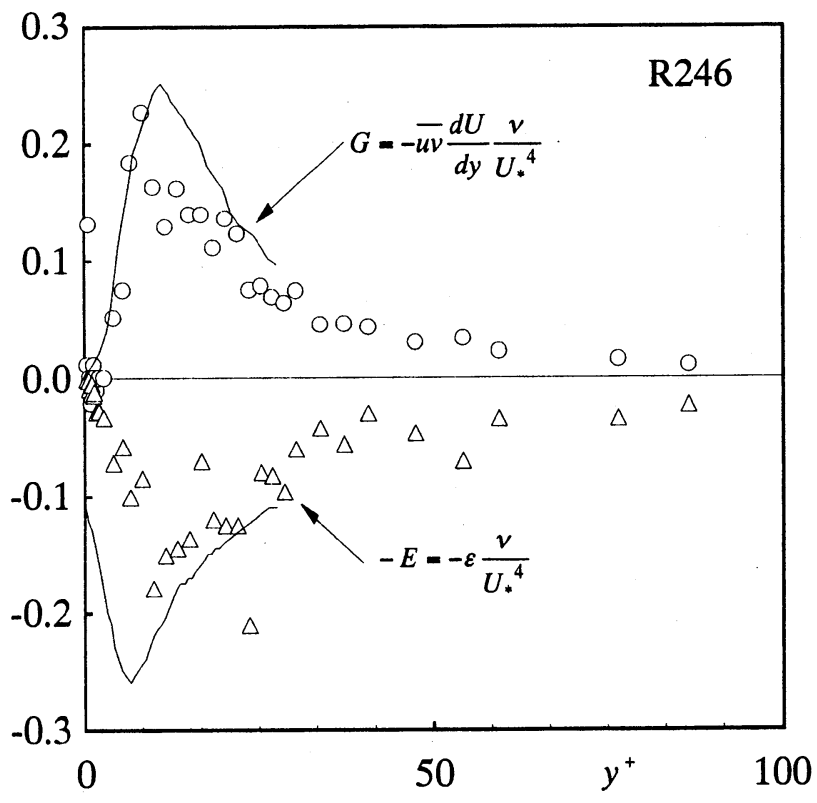

図-10 内層表示によるエネルギー収支

や wake 領域のものよりも狭いことが観察される.こ れは，粘性による影響が卓越しているため，慣性小 領域よりも粘性領域が広いことを意味する。成立範 囲には違いがあるものの $\log$ 則領域および wake 領域 のみならず，粘性底層のスペクトル分布についても 慣性小領域において次式の Kolmogoroff の-5/3 乗則が 成立すると思われる。

$$
E(f)=\frac{A_{s}}{(2 \pi)^{2 / 3}} U^{2 / 3} \varepsilon^{2 / 3} f^{-5 / 3}
$$

ここに, $A_{s}=0.50$ は Kolmogoroff 定数である.なお, $v^{\prime}$ のスペクトルについても同様に慣性小領域で $-5 / 3$ 乗則が認められた。

\section{（7）エネルギー収支}

2 次元開水路等流における乱れエネルギー収支は, 圧力の変動成分を $p$, 横断方向乱れ变動成分を $w$, 散逸率を $\varepsilon$ とすると, 次式で示される.

$$
\begin{gathered}
0=-\overline{u v} \frac{d U}{d y}-\frac{d}{d y}\left\{\overline{\left(k+\frac{p}{\rho}\right)}\right\}-v \frac{d^{2} \bar{k}}{d y^{2}}-\varepsilon \\
k=\frac{1}{2}\left(u^{2}+v^{2}+w^{2}\right)
\end{gathered}
$$

右辺第 1 項は乱れの生成項，第 2 項は乱流拡散項， 第 3 項は粘性拡散項, 第 4 項は粘性散逸項である. 開水路流において，外層表示によるエネルギ一収支 に関しては襧津 ${ }^{2)}$ によって詳細に検討されているが, 内部表示される粘性底層およびバッファー層に関し ては明らかにされていなかった。

先述したように，開水路流における粘性底層およ びバッファー層においても式(14)が成立することが 示されたので, $u^{\prime}$ のスペクトルと式(14)より散逸率 $\varepsilon$ を求めることができる. 図-10は $u_{*}{ }^{4} / v$ で無次元化さ れた乱れの生成率および散逸率を示したもので，実

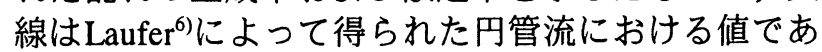

る. 実測值は多少ばらついているが, $y^{+}=10 \sim 15$ 付 近で乱れの生成率及び散逸率が最大をとることがわ かる.また，実測された散逸率はやや小さい值を示 している。これは，底面付近では乱れの異方性が強 まるにも関わらず, 散逸率を $u^{\prime}$ のみから算出したこ

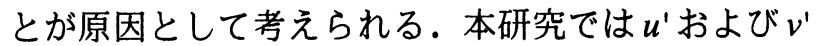
しか計測しておらず，今後 $w^{\prime}$ の計測をする必要があ ろう。しかし，大略的には本実験結果はLaufer ${ }^{6}$ によ る円管流の結果と一致する。これは, 開水路流と管 路流の内層が普遍性を持っていることを示している。

\section{5.おわりに}

2次元開水路等流の粘性底層, バッファー層, $\log$ 則領域およびwake領域を高精度に測定した結果，以 下のような結論が得られた。

(1) 粘性底層およびlog則の主流速分布から求められ る摩擦速度は良好に一致し, 従来より用いられてき た $\log$ 則による摩擦速度の評価が妥当であることが証 明された。

(2) 粘性底層およびバッファー領域における鉛直方 向乱れ強度分布式が新たに提案された。この提案式 に含まれる van Driest のダンピング係数 $B_{v^{\prime}}$ はおよ そ26である。

(3) 主流速分布および流下方向乱れ強度における van Driestのダンピング係数 $B$ および $B_{u^{\prime}}$, 粘性底層に おける流下方向乱れ強度の勾配 $C$ はReynolds数に依 存せずそれぞれ26,10,0.3を示す.

(4) 粘性底層のスペクトル分布においても, 慣性小 領域でKolmogoroffの-5/3乗則が成立する.

(5) 粘性底層及びバッファー層におけるエネルギー 収支は管路流におけるものとほぼ同様な分布となる。

謝辞：本研究を行うに当たり，（社）近畿建設協会 による助成を受けた。ここに，謝意を表する。

\section{参考文献}

1) Nezu, I. and Rodi, W.: Open-channel flow measurements with a laser Doppler anemometer, Journal of Hydraulic Engineering, ASCE, Vol.112, No.5, May, pp.335-355, 1986.

2) 襧津家久: 開水路流の乱流構造に関する基礎的研究, 京 都大学博士論文, 1977.

3) Heisenberg, W.: On the theory of statistical and isotropic turbulence, Proc. Roy. Soc., Ser.A, Vol.195, 1948.

4) 椿 東一郎 - 小松利光:成層密度噴流における乱れおよ び密度変動のスペクトル特性, 土木学会論文報告 集,No.268, 1977.

5) Nezu, I. \& Nakagawa, H.: Turbulence in Open-Channel Flows, IAHR-Monograph, Balkema, Rotterdam, 1993.

6) Laufer, J.: The structure of turbulence in fully developed pipe flow. NACA tech. Rep. No.1174, 1955.

（1997.9.30受付） 